\title{
Menumbuhkan Karakter Anak Usia Dini Melalui Cerita Boneka Tangan dalam Model Tadzkirah
}

\author{
Ridwan Ridwan*, Widi Wulansari \\ 1Program Studi Pendidikan Guru PAUD, Universitas Nusantara PGRI Kediri, Jl. KH. Ahmad Dahlan No. 76, Kediri, Jawa \\ Timur, Indonesia
}

The growth of early childhood character in the golden age is a very important thing that affects behavior and character in the future and it is the responsibility of all parties. Various models, methods and media can be used as a means to grow characters in early childhood. One is using hand puppets through storytelling methods. This research aimed to know how the use of hand puppet through story with tadzkirah model can grow character in early childhood. Kindergarten / PAUD students will be more interested in recognizing characters as well as emulating those characters in the story. Methods of telling stories with hand puppets in line with the Tadzkirah learning model, emphasizing on exemplary (T), guidance on guidance (A), encouragement (D), planting value (Z), continuity principle $(K)$ repetition $(R)$, organizing knowledge and experience $(A)$, touching heart $(H)$. Methods in this study are qualitative methods. The conclusions of this study are the use of hand puppets through story methods and tadzkirah models containing stories of honesty, independence, sense of responsibility and tolerance can grow characters in early childhood.

\section{Keywords: hand puppet, character, Tadzkirah model}

Penumbuhan karakter anak usia dini pada masa golden age merupakan hal yang sangat penting yang mempengaruhi perilaku dan budi pekerti di masa yang akan datang dan hal ini menjadi tanggungjawab semua pihak. Berbagai model, metode maupun media dapat dipakai sebagai sarana untuk menumbuh kembangkan karakter pada anak usia dini. Salah satunya adalah penggunakan boneka tangan melalui metode bercerita. Penelitian ini ditujukan untuk mengetahui bagaimana penggunaan boneka tangan melalui cerita dengan model tadzkirah dapat menumbuhkan karakter pada anak usia dini. Siswa

OPEN ACCESS ISSN 2548-6160 (online)

*Correspondence: Ridwan Ridwan ridwan@unpkediri.ac.id

Citation:

Ridwan R and Wulansari W (2019) Menumbuhkan Karakter Anak Usia Dini Melalui Cerita Boneka Tangan dalam Model Tadzkirah.

Proceeding of the ICECRS. 2:1. doi: 10.21070/picecrs.v2i1.2408
TK/PAUD akan lebih tertarik untuk mengenal karakter sekaligus mencontoh tokoh yang ada pada cerita tersebut. Metode bercerita dengan boneka tangan sesuai dengan model pembelajaran tadzkirah, yang menitikberatkan pada keteladanan $(T)$, arahan bimbingan $(A)$, dorongan $(D)$, penanaman nilai $(Z)$, prinsip kontinuitas $(K)$, pembiasaan dalam berperilaku (I), pengulangan $(R)$, pengorganisasian pengetahuan dan pengalaman $(A)$, sentuhan hati $(H)$. Metode dalam penelitian ini adalah metode kualitatif. Simpulan dari penelitian ini adalah penggunaan boneka tangan melalui metode cerita dan model tadzkirah yang berisi pesan-pesan cerita tentang kejujuran, kemandirian, rasa tanggungjawab dan toleransi dapat menumbuhkan karakter pada anak usia dini.

Keywords: Boneka tangan, karakter, model tadzkirah 


\section{PENDAHULUAN}

Dalam kehidupan manusia, perkembangan pada usia dini merupakan hal yang penting. Karena tidak saja perkembangan fisik tapi juga perkembangan motorik, hal inilah yang dinamakan oleh para ahli merupakan golden age atau usia emas dalam menanamkan berbagai karakter pada anak usia dini. Oleh karena itu, pada masa keemasan ini, meletakan pendidikan dasar terutama karakter adalah fundamental dan akan mempengaruhi perkembangan pribadi selanjutnya Suyadi (2010) . Pada masa inilah, seluruh potensi anak dapat dikembangkan dan hal ini membutuhkan stimuli dan rangsangan dari lingkunganya. Potensi anak usia dini pada dasarnya adalah potensi jasmani dan potensi rohaniah, potensi jasmasi adalah potensi anak akan tumbuh kembang dengan sehat dan potensi karsa, sedangkan potensi jasmani contohnya adalah potensi mereka pengembangan pola pikir, pengembangan rasa Halim (2002) . Potensi rohaniah anak usia dini merupakan hal yang fitrah yang dimiliki oleh seorang anak dan potensi rohaniah inilah yang menjadi dasar dari tumbuh kembangnya potensi-potensi yang lain, tugas dari orang tua, guru dan masyarakat adalah mengembangkan potensi baik rohaniah maupun jasmaniah M (1999). Dalam upaya pengembangan potensi jasmani dan rohaniah anak usia dini, maka perlu ditanamkan pendidikan karakter. Penanaman pendidikan karakter sejak usia dini dapat mengembangkan potensi anak agar terarah dan menjadi lebih baik.

Dalam membentuk karakter anak usia dini dibutuhkan arahan dan bimbingan dari berbagai pihak, baik keluarga, masyarakat dan sekolah. Pada masa anak usia dini penekanan pada perkembangan kognitif yang ditandai dengan anak belum mampu untuk menguasai operasi mental secara logis, oleh sebab itu penggunaan simbol yang mewakili kata-kata, bahasa gerak, benda akan merangsang anak untuk mampu berimajinatif dan berfantasi 549 (2007). Menurut Schulman dan Mekler dalam publikasinya yang berjudul Bringing up a moral child, mengemukakan bahwa ada hal yang sangat penting dalam mendidik anak usia dini yaitu pendidikan moral yang akan membuat anak berperilaku baik (good) dan juga berperilaku adil (just) Schulman and Mekler (1985). Pendidikan moral merupakan salah satu dari karakter yang harus di kembangkan untuk anak usia dini, oleh sebab itu diperlukan pendekatan yang terpadu yang diimplementasikan pada pendidikan disekolah Schaps et al. (2001) .

Pada dasarnya proses belajar mengajar adalah proses komunikasi antara siswa dan gurunya, proses ini lebih efektif apabila dengan menggunakan media pembelajaran. Dengan media melalui proses pembelajaran akan membuat siswa mampu untuk memperoleh pengetahuan, ketrampilan dan sikap Hamdani (2011). Dalam proses belajar mengajar, salah satu unsur yang penting adalah komunikasi antara guru dengan siswa. Komunikasi tersebut sangat efektif apabila dengan menggunakan media pembelajaran untuk menyampaikan pesan atau materi pelajaran. Menurut Gagne dan briggs bahwa pada proses pembelajaran di butuhkan media pembelajaran dalam menyampaikan materi pembelajaran, media tersebut antara lain adalah buku, film, grafik dll. Lebih lanjut menyatakan bahwa media tersebut secara fisik dapat dilihat oleh peserta didik, sehingga mereka tertarik untuk mengikuti pelajaran Arsyad (2002) .

Penggunaan media pembelajaran pada anak usia dini salah satunya adalah menggunakan media boneka tangan yang dikolaborasikan dengan metode bercerita. Metode bercerita dalam hal ini sama dengan metode ceramah, akan tetapi guru lebih seleluasa berimprovisasi dan menceritakan konteks dengan menggunakan ketrampilan yang dimilikinya. Ketrampilannya salah satunya adalah dengan mengatur intonasi suara sesuai dengan suasana yang ingin diceritakan dan juga karakter dari tokoh yang diceritakan. Ketrampilan bercerita yang di dukung dengan penggunaan media seperti boneka tangan, dapat membawa audience yaitu siswa lebih tertarik untuk mengikuti jalan cerita. Metode cerita dengan mendongeng sebuah tokoh pada anak usia dini dapat merangsang imajinasi anak, oleh sebab itu guru di tuntut untuk mempunyai ketrampilan bercerita yang dapat menarik minat siswa dalam mendengar cerita tersebut Hariyanto (2016). Metode bercerita adalah cara menyampaikan materi pembelajaran oleh guru dalam bentuk bercerita kepada peserta didiknya. Pada PAUD/TK, metode ini dipakai untuk menyampaikan pesan moral kepada siswa PAUD, bercerita juga dapat digunakan untuk mengenalkan suatu peristiwa, menjelaskan hal baru, memberi keterangan dalam upaya untuk mengembangkan potensi dasar siswa PAUD/TK. Nurbiana (2007)

Anak usia dini mempunyai kepribadian yang bisa berubah dengan pendidikan, salah satu 
cara adalah dengan pertunjukan boneka yang dapat mempengaruhi kepribadian anak usia dini dikarenakan mereka masih mempunyai daya imajinasi dan inovasi yang besar Vafadary (2009) . Lebih lanjut pertunjukan boneka untuk anak usia dini sebagai sarana untuk mengekspresikan pribadi dan watak yang terwakili dalam boneka tersebut. Boneka tangan tersebut juga merupakan sarana untuk menekspresikan sikap asertif, kemampuan untuk berkomunikasi dengan orang lain dan membantu anak usia dini dalam perkembangan psikologisnya. Ahlcrona menyebutkan bahwa boneka memiliki kemampuan untuk menghubungkan dunia imajinasi anak dengan dunia nyata, anak-anak melalui daya imajinasinya dapat mengetahui dunia nyata dari pertunjukan boneka Ahlcrona (2012) .

Mendengarkan cerita atau dongeng merupakan kegiatan yang menyenangkan bagi anak usia dini apalagi disampaikan dengan cara yang menarik. Anak usia dini menikmati cerita semenjak dia mulai mengerti peristiwa yang terjadi disekitarnya. Hal ini ditandai dari sejak usia 4 sampai 6 tahun anak usia dini mengalami perkembangan kemampuan memahami keadaan disekitarnya Depdiknas (2000) . Kemampuan itu seperti 1) mampu menggunakan kata ganti saya ketika berkomunikasi dengan orang lain 2) mulai berkembang berbagai perbendaharaan kata 3) mulai mampu memahmi suatu peristiwa 4) mulai mampu untuk mengungkapkan perasaan dan pikiran tetapi dengan menggunakan kalimat yang sederhana 5) mampu mengungkapkan sesuatu dengan gambar yang sederhana.

Menurut penelitian Batool Aghajani Boueini, pertunjukan boneka merupakan permainan yang membutuhkan kemampuan yang tinggi, karena memerlukan keahlian dari si pencerita untuk beradaptasi dengan cerita dan figur dari boneka tangan pada situasi yang berbeda. Pertunjukan boneka merupakan wujud cerita dari kehidupan yang nyata, sehingga anak lebih memahami jalan cerita Boueini (2014) . Batool Aghajani Boueini, dalam penelitiannya tersebut lebih lanjut, Batool menjelaskan bahwa perlu di ajarkan ketrampilan sosial pada anak sedini mungkin. Pembelajaran tentang ketrampilan sosial dengan menggunakan bantuan boneka tangan akan meningkatkan kemampuan anak untuk berinteraksi dengan orang lain selain mempunyai empati terhadap orang lain dan lingkungannya. Bercerita merupakan kegiatan yang terintegral dalam kehidupan anak usia dini selama beberapa tahun yang lalu, orang tua biasanya menceritakan sebuah cerita kepada anaknya untuk mengajarkan arti kehidupan dan pelajaran moral. Bahan cerita bisa dengan menggunakan contoh binatang seperti rubah yang berbohong atau kelinci yang sombong. Dan cerita tersebut akan menjadi lebih menarik apabila dengan menggunakan bantuan boneka tangan Marriott (2002) .

Penelitian dari Larsen, Lee, Ganea, menunjukan bahwa kegiatan bercerita untuk anak kecuali sebagai hiburan, juga untuk memberikan pelajaran moral untuk berperilaku yang baik. Dengan bercerita, penyampaian tentang karakter yang baik dapat tersampaikan pada anak usia dini. Pendidikan karakter pada anak pra sekolah menjadi sangatlah penting, melalui kegiatan berceritalah penyampaian tentang karakter baik dengan cerita manusia atau binatang dapat tersampaikan Larsen et al. (2016) . Kegiatan bercerita dengan menggunakan media boneka tangan untuk penanaman moral dan karakter dapat di wujudkan dalam empat model yaitu model terintegrasi dalam pelajaran, model di luar pelajaran dan model gabungan Suparno (2002) . Pada anak usia dini. Kegiatan bercerita sejatinya adalah untuk mengembangkan daya imajinasi anak, meningkatkan berbahasa anak, membangun kecerdasan emosional anak dan membentuk rasa empati anak. Kegiatan bercerita dengan menggunakan boneka tangan, tentu saja akan menampilkan tokoh yang mempunyai karakter sesuai dengan jalan cerita. Dalam penelitian ini karakter dalam cerita dikembangkan dengan model tadzkirah.

Menurut Ninsiana Widhiya, bahwa model pendidikan karakter dalam bentuk pemberian contoh keteladanan yang dikenal dengan model tadzkirah. Model ini di turunkan dari model pembelajaran dalam teori Islam yaitu tadzkiroh yang merupakan unsure-unsur dari 1) keteladanan (T), 2) arahan (A) dengan memberikan bimbingan 3) Dorongan (D) dengan memberikan motivasi kepada anak usia dini 4) Zakiyah (Z) keikhlasan hati dari pendidik untuk memberi pengetahuan, ketrampilan dan keteladanan pada anak usia dini 5) Komuninitas (K) yaitu dengan pembiasaan dalam hal pendidikan moral yang positif 6) Ingatkan (I) selalu mengingatkan pada anak didik bila melakukan kesalahan 7) Repetisi (R) selalu mengulangulang pembelajaran pada anak usia dini sehingga menjadi suatu kebiasaan 8) Organisasikan (O) mengorganisasikan pengetahuan dan pengalaman anak usia dini yang berasal dari luar 
sekolah sebagai informasi yang tepat untuk proses pembelajaran di kelas 9) Heart (H) seorang pendidik dalam memberikan materi pembelajaran pada anak usia dini dapat menyentuh hati dan kalbu anak sehingga pelajaran dapat diterima dengan baik. Pembelajaran karakter dengan model tadzkirah di desain sedemikian rupa sesuai dengan usia perkembangan anak melalui permainan boneka tangan sehingga pembelajaran moral dari tokoh yang diperankan boneka tangan dapat tersampaikan Ninsiana (2016) .

Sejalan dengan penumbuhan karakter anak usia dini, wolfgang mengemukakan bahwa anak usia dini merupakan anak didik yang aktif yang secara terus menerus mendapatkan informasi dari dunia permainannya. Disamping itu anak usia dini selalu mengalami kemajuan dalam hal fisik maupun non fisik. Ketergantungan pada orang dewasa sangat besar sehingga anak usia dini membutuhkan interaksi sosial untuk dapat menumbuhkan emosi maupun kognitifnya. Wolfgang juga mengatakan bahwa anak adalah individu yang unik, dimana tumbuh kembang antar anak yang satu dan yang lain berbeda-beda demikian juga dalam penumbuhan dan pengembangan karakternya Wolfgang (1992) .

Berdasarkan latar belakang diatas, maka betapa pentingnya menumbuhkan karakter positif anak sejak usia dini yang dilakukan pada lingkungan keluarga, masyarakat maupun sekolah. Penumbuhan dan pengembangan karakter dapat di integraskan pada proses belajar mengajar di PAUD/TK. Dalam proses belajar mengajar tentu saja diperlukan model, metode dan juga pendekatan sehingga tujuan dari pembelajaran dapat tercapai. Pada penumbuhan dan pengembangan karakter anak usia dini diperlukan strategi maupun metode yang tepat sehingga pesanpesan moral yang terkandung dalam karakter dapat terwujud. Oleh sebab itu model tadzkirah dengan menggunakan media boneka tangan diharapkan dapat mempermudah penyampaian karakter-karakter positif dari tokoh yang diceritakan yang nantinya dapat di tiru oleh anak usia dini. Fokus masalah dalam penelitian ini adalah mendeskripsikan penggunaan boneka tangan melalui cerita dengan model tadzkirah yang akan menumbuhkan karakter anak usia dini. Nilai karakter model tadzkirah berbantuan boneka tangan di fokuskan pada karakter jujur, mandiri, tanggungjawab dan tolesansi. Sehingga tujuan dari penelitian ini adalah bagaimana penggunaan boneka tangan dengan model tadzkirah yang di implementasikan dalam proses belajar mengajar dapat menumbuhkan karakter anak usia dini.

\section{METODE PENELITIAN}

Jenis penelitian ini adalah penelitian kualitatif dengan pendekatan deskriptif. Penelitian ini berupaya untuk mendeskripsikan, mencatat dan juga menganalisis serta menganalisa penggunaan boneka tangan dengan model tadzkirah untuk menumbuhkan karakter anak usia dini. Pendekatan deskriptif digunakan karena pendekatan ini mengumpulkan informasi serta menggambarkan tentang variabel, gejala, keadaan dan bukan untuk mengukur hipotesis tertentu Arikunto (1998). Sedangkan Moleong mengemukakan bahwa pendekatan kualitatif merupakan prosedur penelitian dengan menggunakan data deskriptif yang berupa kata-kata tulisan atau lisan dari subyek yang akan diamati Moleong (2008).

Subyek penelitian ini adalah guru dan siswa PAUD kelompok B yang berjumlah 16 siswa pada PAUD GS Buah Hati Kota Kediri. Sedangkan teknik pengumpulan data dengan menggunakan teknik wawancara, observasi. Peneliti sebagai pengamat dari kegiatan yang dilaksanakan oleh guru dan siswa PAUD. Teknik wawancara dilakukan dalam rangka untuk menggali infomasi yang terkait dengan penggunaan boneka tangan serta implementasi yang pernah dilaksanakan dalam proses pembelajaran. Teknik dokumentasi yang digunakan untuk mendukung dan melengkapi informasi tentang pembelajaran dengan menggunakan boneka tangan dan model tadzkiran adalah dengan Rencana Pelaksanaan Pembelajran Harian (RPPH) dan Rencana Pelaksanaan Pembelajaran Mingguan. Teknik Observasi digunakan dengan mengobservasi pelaksanaan pembelajaran dengan media boneka tangan dan model tadzkirah. Data yang dikumpulkan akan di analisis untuk diambil kesimpulannya.

Teknik analisis data dalam penelitian ini dengan menggunakan Miles dan Huberman yaitu dengan menggunakan 3 (tiga) langkah yaitu reduksi data (reduction), penyajian data (data display) dan penarikan kesimpulan (conclusion drawing/verivication) Sugiyono (2013) . Uji keab- 
sahan data melalui uji kredibilitas, uji transferabilitas, uji dependibilitas dan uji komformabilitas Yusuf (2014).

\section{HASIL DAN PEMBAHASAN}

Dari hasil wawancara, observasi dan dokumentasi yang dilakukan dalam penelitian ini pada PAUD GS Buah Hati Kota Kediri, diperoleh hasil bahwa guru pada PAUD GS Buah hati sering menggunakan media boneka tangan maupun boneka jari tapi hanya sebatas pada karakter yang sederhana. Selain digunakan dalam bercerita, boneka tangan juga digunakan sebagai mengajak siswa PAUD untuk bernyanyi sesuai dengan karakter yang ada dalam cerita tersebut. Boneka tangan yang dipakai hanya sebagai media memotivasi siswa untuk lebih fokus terhadap cerita yang diberikan oleh guru. Hasil wawancara dengan guru Insiyah sebagai berikut :

"memang sering menggunakan boneka tangan, boneka jari, tetapi hanya sekedar siswa biar lebih fokus, karena biasanya anak kecil itu sukanya hal-hal yang baru, suka juga mendengarkan cerita. Hanya sayangnya yang kita ceritakan banyak cerita fabel, yaitu tokoh-tokoh binatang" (Indiyah, 2 April 2019).

Dalam pelaksanaan pembelajaran guru menggunakan media boneka tangan pada kelompok B, yang berjumlah 19 siswa. Dalam pembuatan boneka tangan, beberapa ada yang dibuat oleh guru dengan cara yang sederhana, dan ada beberapa yang membeli. Penggunaan boneka tangan digunakan secara fleksibel, akan tetapi sering digunakan ketika guru bercerita. Dalam observasi diperoleh data, bahwa kegiatan bercerita dengan menggunakan boneka tangan lebih efektif apabila guru menggunakan latar setting yang dibuat sendiri sebagai latar dari pertunjukan boneka tangan "dari beberapa kegiatan yang pernah kita lakukan, kita berusaha membuat latar belakang untuk pertunjukan boneka tangan, kadang kita pakai taplak yang berwarna hijau dan kontras, ada beberapa pohon-pohon yang kita buat secara sederhana, dan memang anak-anak lebih tertarik kalau kita bercerita, sering mereka minta untuk bercerita. (Indiyah, 6 Mei 2019).

Dari observasi selama 2 bulan, guru melakukan 6 kali kegiatan bercerita dengan menggunakan boneka tangan dan hanya 2 kali dengan menggunakan buku cerita. Dalam hal ini dapat diperoleh kesimpulan bahwa guru lebih dominan dalam menggunakan media boneka tangan dalam menyampaikan cerita dalam upaya membangun motivasi siswa untuk lebih tertarik dengan cerita yang dilakukan oleh guru. Kegiatan bercerita dengan menggunakan boneka tangan yang dilakukan didepan kelas disesuaikan dengan RKH yang sudah dibuat oleh guru. Pada lain kesempatan, guru mencoba untuk memberikan kesempatan kepada siswa untuk mencoba boneka tangan dan bercerita tentang keadaan diri siswa (pada tema pengenalan diri dan sub tema aku diciptakan oleh Tuhan). Boneka tangan yang di gunakan oleh siswa adalah boneka tangan yang digunakan oleh guru sebagai media guru dalam bercerita pada hari yang sama, ataupun boneka tangan yang dipilih sendiri oleh siswa.

Dalam pelaksanaannya, guru memotivasi siswa agar aktif merespon alur cerita yang dilakukan oleh guru, mendorong siswa untuk berani bertanya maupun menanggapi cerita dari guru. Dan diakhir kegiatan, siswa di ajak berkomunikasi tentang apa yang sudah diceritakan, dan di selipi dengan pesan pesan moral. Adapun kegiatan pelaksanaan bercerita dengan menggunakan media boneka tangan dan model tadzkirah dapat dilihat pada Tabel 1 


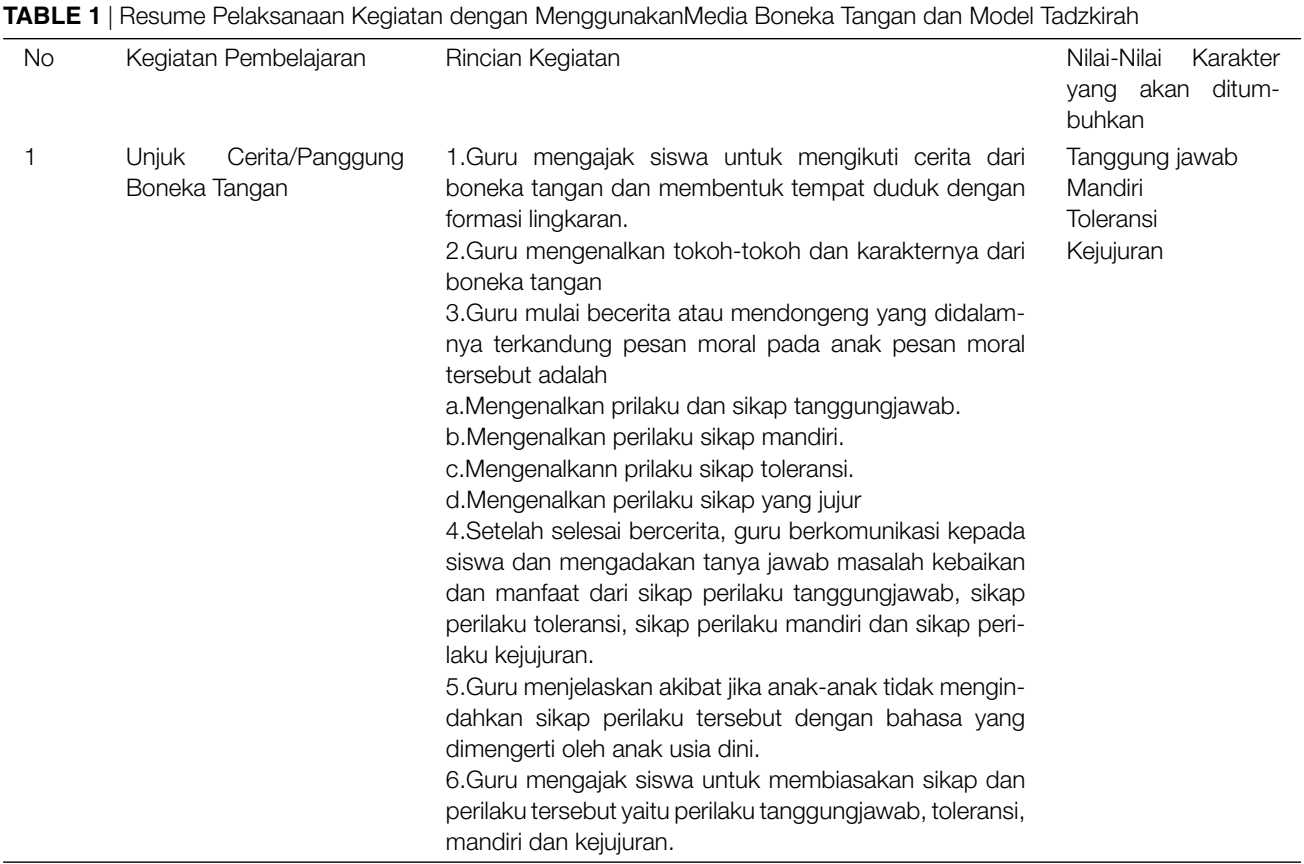

Untuk mendapatkan hasil maksimal dan upaya menanamkan karakter yang ada pada taabel 1, dilanjutkan dengan kegiatan pembelajaran sebagai implementasi dari isi pesan dalam kegiatan belajar unjuk cerita/panggung boneka tangan. Siswa tidak hanya mengenal karakter melalui isi cerita (dongeng) tetapi juga mereka mengalami secara langsung melalui kegiatan belajar yang melibatkan mereka secara aktif sekaligus menumbuh kembangkan nilai karakter mandiri, tanggungjawab, toleransi dan jujur dengan pembiasaan sikap dan perilaku dalam kehidupan sehari-hari. Kegiatan belajar tersebut dapat disusun dalam rencana kegiatan pembelajaran harian dalam Tabel 2 .

Dari tabel 2 ditunjukan bagaimana menumbuh kembangkan nilai-nilai karakter anak usia dini diantaranya tanggungjawab, mandiri, toleransi dan jujur melalui kegiatan pembelajaran dengan menggunakan media atau APE boneka tangan dengan metode bercerita dan model tadzkirah, juga implementasinya dalam kegiatan belajar dan aktivitas siswa. Sejalan dengan penelitian Canon M.Walkerr dan Tania Lombrozo, bahwa cerita atau mendongeng dengan menggunakan boneka berpengaruh terhadap pengembangan moral anak usia dini dengan usia antara 5 - 6 tahun. Dengan mendengar cerita dengan media boneka, pesan-pesan moral yang terkandung dalam cerita tersampaikan pada anak usia dini yang pada akhirnya berpengaruh pada pengembangan moral Walker (2017) . 
TABLE 2 | Kegiatan Pembelajaran Penerapan Nilai KarakterDengan Menggunakan Boneka Tangan

\begin{tabular}{|c|c|c|c|}
\hline No & Keterangan & Rincian Kegiatan Pembelajaran & $\begin{array}{l}\text { Nilai-Nilai Karakter } \\
\text { yang akan ditum- } \\
\text { buhkan }\end{array}$ \\
\hline 1 & $\begin{array}{l}\text { Merapikan mainan } \\
\text { boneka tangan dengan } \\
\text { rapi }\end{array}$ & $\begin{array}{l}\text { 1. Guru mengajak siswa untuk merapikan boneka tangan } \\
\text { yang sudah digunakan } \\
\text { 2. Siswa diajak mengikuti recalling (mengikuti materi yang } \\
\text { sudah dibahas sebelumnya dengan bahasa anak usia } \\
\text { dini seperti apa yang dirasakan oleh siswa, apa yang di } \\
\text { mengerti dan apa yang difikirkan oleh siswa) dan mem- } \\
\text { inta siswa untuk menjawab pertanyaan dari guru. } \\
\text { 3. Guru mengapresiasi siswa karena mereka sudah } \\
\text { mampu merapikan media boneka tangan yang sudah } \\
\text { digunakan. } \\
\text { 4. Guru menyampaikan pesan yang terdapat dalam cerita } \\
\text { sehingga siswa dapat memahami dan mengerti pesan } \\
\text { moral tersebut. } \\
\text { 5. Guru memberikan contoh tanggungjawab dan mandiri } \\
\text { seperti bagaimana merapikan boneka tangan yang } \\
\text { sudah digunakan pada tempat yang telah tersedia secara } \\
\text { mandiri tanpa bantuan dari orang lain } \\
\text { 6. Guru mengajak anak untuk membiasakan sifat tang- } \\
\text { gungjawab dan mandiri disetiap kegiatan sekolah dan } \\
\text { dirumah. }\end{array}$ & $\begin{array}{l}\text { Tanggungjawab dan } \\
\text { Mandiri }\end{array}$ \\
\hline 2 & $\begin{array}{l}\text { Berdiskusi dengan sikap } \\
\text { toleransi }\end{array}$ & $\begin{array}{l}\text { Melalui kegiatan bercerita dengan boneka tangan : } \\
\text { 1.Guru mengajak anak untuk mengenali identitas } \\
\text { masing-masing pemeluk agama } \\
\text { 2.Guru mengenalkan arti sikap toleransi dalam kegiatann } \\
\text { keseharian } \\
\text { 3.Guru member contoh nyata bagaimana bertoleransi } \\
\text { itu dilakukan dalam kegiatan disekolah dan dilingkungan } \\
\text { masyarakat } \\
\text { 4.Guru berkomunikasi dan mendiskusikan dengan } \\
\text { bahasa anak usia dini tentang perilaku yang boleh dan } \\
\text { yang tidak boleh dilakukan oleh anak sebagai penguatan } \\
\text { sikap toleransi mereka. } \\
\text { 5.Guru mengajak anak untuk membiasakan berpeerilaku } \\
\text { toleran dengan teman atau orang lain yang berbeda } \\
\text { agama. }\end{array}$ & \\
\hline 3 & $\begin{array}{l}\text { Panggung cerita boneka } \\
\text { tangan }\end{array}$ & $\begin{array}{l}\text { 1. Guru mengenalkan boneka tangan dan karakter yang } \\
\text { ada dari boneka tersebut. } \\
\text { 2. Guru memainkan boneka tangan dengan karakter } \\
\text { (tokoh si jujur dan si pembohong). } \\
\text { 3. Guru mengenalkan sifat jujur dan berbohong yang } \\
\text { dikemas dalam cerita atau dongeng } \\
\text { 4. Guru mengajak anak untuk menyimak dan mem- } \\
\text { perhatikan cerita tersebut dan mendiskusikan tentang } \\
\text { kebaikan dan keburukan sifat jujur dan sifat pembohong. } \\
\text { Guru mengajak anak untuk membiasakan bersikap jujur } \\
\text { dalam kegiatan di sekolah dan dirumah. }\end{array}$ & Kejujuran \\
\hline
\end{tabular}

\section{KESIMPULAN}

Berdasarkan hasil dan pembahasan dalam penelitian ini dapat disimpulkan bahwa dalam upaya menumbuhkan karakter anak usia dini melalui cerita boneka tangan dan model tadzkirah, guru harus merencanakan kegiatan tersebut melalui rencana kegiatan pelaksanaan harian maupun rencana kegiatan pelaksanaan mingguan, sehingga karakter yang dibangun dapat tercapai. Kegiatan bercerita dengan menggunakan boneka tangan dan model tadzkirah akan dapat berhasil apabila melibatkan siswa secara aktif baik pada saat pelaksanaan pembelajaran maupun ketika pelajaran usai. Penumbuhan karakter tanggung jawab, mandiri, toleransi dan jujur akan dapat berhasil apabila disertai dengan sikap perilaku dan pembiasaan sehari-hari.

Berdasarkan kesimpulan yang telah di jabarkan diatas, peneliti menyarankan bahwa penggunaan boneka tangan dengan model tadzkirah sebaiknya juga dilakukan tidak hanya PAUD 
kelompok B, tetapi juga PAUD kelompok A, sehingga penumbuhann karakter tanggung jawab, mandiri, toleransi dan kejujuran dimulai sejak anak masuk pendidikan anak usia dini. Media boneka tangan sebaiknya dapat digunakan juga dalam mengembangkan karakter anak selain karakter yang diteliti misalkan karakter religius, bersyukur, kreatif, keteladanan, dan lain-lain sebagai penelitian lanjut.

\section{REFERENCES}

(2007). Syamsu Yusuf, Psikologi Perkembangan Anak dan Remaja (Bandung: Remaja Rosda Karya)

Ahlcrona, M. R. (2012). The Puppet's Communicative Potential As A Mediating Tool In Preschool Education. International Journal of Education Communication 44, 171-184

Arikunto, S. (1998). Manajemen Penelitian (Jakarta: Rineka Cipta)

Arsyad, A. (2002). Mediaa Pembelajaraan (Jakarta: Rajawali Pers)

Boueini, B. A. (2014). Teaching Social Skills To Children Through Puppetry (Case Study Of Institute For The Intellectual Development Of Children And Young Adults, Fouman. Indian Journal of Fundamental and Applied Life Sciences , 1696-1702

Depdiknas (2000). Modul Pelatihan Pengelola dan Tenaga Pendidik Kelompok Bermain (Jakarta: Departemen Pendidikan Nasional)

Halim, M. (2002). Nipan Abdul, Anak Saleh Dambaan Keluarga (Yogyakarta: Mitra Pustaka)

Hamdani (2011). Strategi Belajar Mengajar (Bandung: CV Pustaka Setia)

Hariyanto, M. S. (2016). Konsep dan Model Pendidikan Karakter (Badung: PT. Rosdakarya)

Larsen, N. E., Lee, K., and Ganea, P. A. (2016). Do storybooks with anthropomorphized animal characters promote prosocial behaviors in young children? Wiley development science

M, F. T. (1999). Pengasuhan Anak dalam Keluarga Islam (Jakarta: Lembaga Agama)

Marriott, S. (2002). Red in tooth and claw? Images of nature in modern picture books. Children's Literature in Education $33,175-183$

Moleong, L. J. (2008). Metodologi Penelitian Kualitatif (Bandung: Remaja Rosda Karya)

Ninsiana, W. (2016). Kontribusi Model Tadzkirah Dalam Pengajaran Dan Pembelajaran Bahasa Inggris Berkarak- ter Pada Anak Usia Dini, Elementary Jurnal Ilmiah Pendidikan. Elementary 2

Nurbiana, D. (2007). Metode Pengembangan Bahasa (Jakarta:Universitas Terbuka)

Schaps, E., Schaeffer, E. F., and McDonell, S. N. (2001). What's Right and Wrong

Schulman, M. and Mekler, E. (1985). Bringing Up a Moral Child (Reading: Addison-Wesley Publising Company Inc)

Sugiyono (2013). Metode Penelitian Pendidikan (Bandung: Alfabeta)

Suparno, P. (2002). Moerti Yoedho Koesoemo, Detty Titisati, A.l., Pendidikan budi pekerti di sekolah: sebuah tinjauan umum (Yogyakarta: Kanisius)

Suyadi (2010). Psikologi Belajar PAUD Pendidian Anak Usia Dini (Yogjakarta: Pedagogia)

Vafadary, Y. (2009). The value of children's educational theater. Fine Arts Magazine 40, 66-69

Walker, C. M. (2017). Tania Lombrozo, Explaining The Moral Of The Story, Cognition 167

Wolfgang, C. W. M. E. (1992). School for Young Children: Developmentally Approriate Practice (USA: Allyn)

Yusuf, A. M. (2014). Metode Penelitian Kuantitatif, Kualitatif, dan Penelitian Gabungan (Jakarta: Prenada Media Group)

Conflict of Interest Statement: The authors declare that the research was conducted in the absence of any commercial or financial relationships that could be construed as a potential conflict of interest.

Copyright (c) 2019 Ridwan and Wulansari. This is an openaccess article distributed under the terms of the Creative Commons Attribution License (CC BY). The use, distribution or reproduction in other forums is permitted, provided the original author(s) and the copyright owner(s) are credited and that the original publication in this journal is cited, in accordance with accepted academic practice. No use, distribution or reproduction is permitted which does not comply with these terms. 